\title{
Improving the Desulphurization in COREX-3000 Process by the Optimization of Chemical Compositions of Slag
}

\author{
Shengli WU, Laixin WANG, ${ }^{*}$ Yanan LU and Kai GU \\ School of Metallurgical and Ecological Engineering, University of Science and Technology Beijing, 30 Xueyuan Road, Haidian \\ District, Beijing, 100083 P. R. China. \\ (Received on June 11, 2018; accepted on July 19, 2018; J-STAGE Advance published date: August 27, \\ 2018)
}

\begin{abstract}
To improve the desulfurization in the COREX-3000 process, several aspects are studied and practiced. The work documented in the present paper focuses on the effects of chemical compositions of slag, such as $\mathrm{CaO} / \mathrm{SiO}_{2}, \mathrm{MgO}, \mathrm{MgO} / \mathrm{Al}_{2} \mathrm{O}_{3}$ and $\mathrm{MnO}$, on desulfurization. Theoretical calculations of sulfide capacity and viscosity of slag and diffusion coefficient of $\mathrm{S}^{2-}$ in the slag are given to study the effects of slag chemical compositions on the thermodynamics and dynamics of desulfurization. After that, experiments are carried out to verify the theoretical analyses and give the appropriate ranges of these four parameters. The suggested suitable ranges of $\mathrm{CaO} / \mathrm{SiO}_{2}, \mathrm{MgO}$ content, $\mathrm{MgO} / \mathrm{Al}_{2} \mathrm{O}_{3}$ and $\mathrm{MnO}$ content for COREX-3000 are 1.20-1.30, $10 \mathrm{wt} \%-12 \mathrm{wt} \%, 0.80-0.90$ and $0.4 \mathrm{wt} \%-0.7 \mathrm{wt} \%$, respectively.
\end{abstract}

KEYWORDS: sulfide capacity; sulfur distribution ratio; viscosity; diffusion coefficient; polymerization degree; desulfurization efficiency.

\section{Introduction}

Extensive efforts have been undertaken due to environmental pressures and the increasing scarcity of good quality coking coal to develop alternative processes for iron-making to the conventional blast furnace route. So far, COREX, a smelting reduction process, has emerged as one of the most promising alternatives. It is the first commercially established and industrially proven smelting reduction process based mainly on non-coking coal, which capable of meeting the economical and environmental requirements. ${ }^{1-3)}$ However, the COREX-3000, designed productivity of which is 1.5 million tons per year, still has some disadvantages. For example, the sulfur content of COREX hot metal (HM) is higher on average and has more severe fluctuations than that of the blast furnace (BF). The detailed description of the problem in COREX hot metal and transfer process of sulfur were listed in the authors' previous paper. ${ }^{4}$

Sulphur is a problematic impurity in the steelmaking industry that contributes to the embrittlement of steel on account of the formation of continuous intergranular liquid films in the solidified steel. This promotes intergranular weakness and solidification cracking of the metal. ${ }^{5}$ Accordingly, the desulfurization of hot metal is a vital part of the steelmaking process since sulfur in many steel products is detrimental. In general, desulfurization of hot metal is more economical than desulfurization of steel, and about 90 pct of the hot metal produced in blast furnace is desulfurized before it is sent to be processed in a steelmaking furnace. ${ }^{\text {) }}$

* Corresponding author: E-mail: wanglaixinustb@163.com

DOI: https://doi.org/10.2355/isijinternational.ISIJINT-2018-427
So far, many research works in desulfurization have been carried out in the context of BF slags and ladle slags. ${ }^{70}$ ) However, it should be stressed that the composition of slag in COREX process was different from those of $\mathrm{BF}$ and ladle slags. So it's worthwhile to study the desulfurization in COREX process and method of adjusting chemical compositions of hot metal has been expounded in the former paper. $^{11)}$

In this paper, theoretical analysis has been carried out firstly to study the influence of chemical compositions of COREX slag, such as binary basicity, $\mathrm{MgO}$ and $\mathrm{MnO}$, on the sulfide capacity and viscosity. After that, experiments were carried out to verify the influence of chemical compositions of slag on the desulfurization efficiency and give the suitable compositions of slag for COREX-3000.

\section{Theoretical Background}

\subsection{Calculation of $C_{S}$ and $L_{S}$}

The concept of sulfide capacity $\left(C_{S}\right)$ is clearly of great importance in relation to the desulfurization of pyrometallurgical process, which is the main parameter in the following theoretical analysis. The sulfide capacity is a property of the slag, which is dependent only on the temperature and the slag composition. It describes the potential ability of an arbitrary homogeneous molten slag to remove sulfur, and it could be used to compare the desulphurization characteristics of different slags. ${ }^{12}$ ) The sulfide capacity was defined by Fincham and Richardson, which is shown in Eq. (3). ${ }^{13)}$

$$
C_{S}=(p c t S)\left(\frac{p_{O_{2}}}{p_{S_{2}}}\right)^{1 / 2}
$$


where $p_{\mathrm{O}_{2}}$ and $p_{S_{2}}$ are the partial pressures of $\mathrm{O}_{2}(\mathrm{~g})$ and $\mathrm{S}_{2}(\mathrm{~g})$, respectively. (pct $\mathrm{S}$ ) is the sulfur content of slag in wt pct.

Effect of oxides on the sulfide capacity are determined not only the concentration of free oxygen that is bond with metal cation M only but also the stability of the formed sulfide MS. High concentration of free oxygen and higher stability of the sulfides can increase the sulfide capacity. For example, the order of free oxygen concentration in binary $\mathrm{MO}-\mathrm{SiO}_{2}$ slags with the same contents of $\mathrm{SiO}_{2}$ is $\mathrm{FeO}-\mathrm{SiO}_{2}>\mathrm{MnO}-\mathrm{SiO}_{2}>$ $\mathrm{MgO}-\mathrm{SiO}_{2}>\mathrm{CaO}-\mathrm{SiO}_{2}$, while order of the sulfide stability is $\mathrm{CaS}>\mathrm{MnS}>\mathrm{FeS}>\mathrm{MgS}$. Both factors contribute to the order of sulfide capacity for binary $\mathrm{MO}-\mathrm{SiO}_{2}$ systems with same content of $\mathrm{MO}$ at the same temperature follows the order $\mathrm{MnO}-\mathrm{SiO}_{2}>\mathrm{FeO}-\mathrm{SiO}_{2}>\mathrm{CaO}-\mathrm{SiO}_{2}>\mathrm{MgO}-\mathrm{SiO}_{2} .{ }^{14,15)}$ Therefore, Zhang's model (Eq. (2)) was adopted to calculate the sulfide capacity in this article as it is easier for calculation and has wider scope of application and higher accuracy.

$$
\log C_{S}=-6.08+4.49 / \Lambda+(15893-15864 / \Lambda) / T
$$

where $\Lambda$ is the optical basicity, which is calculated by Eq. $(3),{ }^{16)}$ and $\mathrm{T}$ is the temperature, $\mathrm{K}$.

$$
\Lambda=\frac{\sum N_{i} X_{i} \Lambda_{i}}{\sum N_{i} X_{i}}
$$

where $N_{i}$ is the number of oxygen in component $\mathrm{i} ; X_{i}$ is the mole fraction of component $\mathrm{i} ; \Lambda_{i}$ is the optical basicity of component i (Listed in Table 1), respectively.

Relationship between sulfur distribution ratio $\left(L_{S}\right)$ with $C_{S}$ has been deduced and expounded in the former paper ${ }^{11)}$ and it is shown as Eq. (4).

$$
\lg L_{S}=\lg C_{S}+\lg \left(f_{S} f_{C}[\text { pct } \mathrm{C}]\right)+\frac{100.366}{T}+2.895
$$

Where $f_{s}$ and $f_{c}$ are activity coefficients of respective sulfur and carbon in hot metal relative to the $1 \mathrm{wt}$ pct standard state, [pct C] is the carbon content in hot metal.

The activity coefficient is calculated using Wagner's equation: ${ }^{16)}$

$$
\log f_{j}=\sum\left(e_{j}^{i}[\% i]\right)
$$

where $f_{j}$ is the activity coefficient for element $j$ in the hot iron, $i$ represents the dissolved elements in the hot iron, and $e_{j}^{i}$ is the interaction parameter for element $j$. The interaction parameters in the present case were taken from a publication

Table 1. Optical basicity of different oxides. ${ }^{14}$

\begin{tabular}{ccccccc}
\hline Oxides & $\mathrm{CaO}$ & $\mathrm{MgO}$ & $\mathrm{Al}_{2} \mathrm{O}_{3}$ & $\mathrm{SiO}_{2}$ & $\mathrm{FeO}$ & $\mathrm{MnO}$ \\
\hline $\begin{array}{l}\text { Optical } \\
\text { basicity }\end{array}$ & 1 & 0.78 & 0.61 & 0.48 & 1.24 & 1.43 \\
\hline
\end{tabular}

Table 2. Interaction parameters among different elements in hot metal. $^{19)}$

\begin{tabular}{ccccc}
\hline & \multicolumn{5}{c}{$j$} \\
\cline { 2 - 5 }$i$ & $\mathrm{Si}$ & $\mathrm{Mn}$ & $\mathrm{C}$ & $\mathrm{S}$ \\
\hline $\mathrm{S}$ & 0.063 & -0.026 & 0.110 & -0.028 \\
$\mathrm{C}$ & 0.080 & -0.012 & 0.140 & 0.046 \\
\hline
\end{tabular}

by Liang and Che ${ }^{17)}$ and listed in Table 2.

\subsection{Calculation of Viscosity and Diffusion Coefficient of Sulfur in the Slag}

The rate-controlling step of desulfurization reaction between hot metal and slag is the diffusion process of sulfur in the slag, which has been analyzed in the former paper. ${ }^{11)}$ The diffusion coefficient of sulfur in the slag can be calculated as shown in Eq. (6).

$$
D=\frac{R T}{N_{0}} \cdot \frac{1}{6 \pi r \cdot \eta}
$$

where $D$ is the diffusion coefficient of sulfur in the slag, $R$ is the molar gas constant, $N_{0}$ is the Avogadro constant, $r$ is the radius of $\mathrm{S}^{2-}, \eta$ is the viscosity of slag, and $\mathrm{T}$ is the temperature, $\mathrm{K}$.

In the present paper, adjustments of chemical compositions of COREX slag would have an effect on the viscosity of slag and so influence the diffusion coefficient of sulfur in the slag. The influence of chemical composition of COREX slag on the kinetic conditions of desulfurization reaction will be discussed in Part 3.

The viscosity of silicate slag plays significant roles in ironmaking and steelmaking processes, which are not only closely related to the practical operation but also are intimately associated with the diffusion controlled kinetics. Therefore, considerable attentions should be paid on viscosity of slag for its great importance in understanding the desulfurization reaction kinetics in COREX process.

The rheological properties of liquid suspensions have been studied since many years ago, by Einstein (Eq. (7)). ${ }^{18)}$ Many years later, Brinkman modified and generalized the Einstein formula to determine the effective viscosity of the slag, Eq. (8). ${ }^{19-21)}$

$$
\begin{aligned}
& \eta=\eta_{0}(1+2.5 \varphi) \\
& \eta=\eta_{0}(1-\varphi)^{-2.5}
\end{aligned}
$$

where $\eta$ and $\eta_{0}$ are the viscosity of the solid-containing and the solid-free slag, respectively; $\varphi$ is the volume fraction of solid particles in the slag. In this paper, $\eta_{0}$ and $\varphi$ of different slags were calculated by FactSage 6.4 and the viscosity of slag will be calculated by Eq. (8) based on the results of FactSage.

\section{Theoretical Calculations and Analyses}

\subsection{Theoretical Calculations of $C_{S}$ and $L_{S}$ (Thermody- namics)}

It's necessary to have a theoretical cognition of the effects of slag chemical compositions on desulfurization in thermodynamics and dynamics. Firstly, theoretical calculations of thermodynamics are discussed based on Eqs. (2) and (4).

\subsubsection{Effect of Binary Basity $\left(\mathrm{R}_{2}\right)$}

The calculated $C_{S}$ and $L_{S}$ at $1773 \mathrm{~K}\left(1500^{\circ} \mathrm{C}\right)$ are plotted against binary basicity and shown in Fig. 1. In Fig. 1, the temperature, compositions of hot metal and all the other oxides contents are maintained, while only the $\mathrm{CaO} / \mathrm{SiO}_{2}$ in the slag is allowed to vary. As seen in the figure, $C_{S}$ and $L_{S}$ increase with increase of $R_{2}$. In the slag, at lower oxygen 


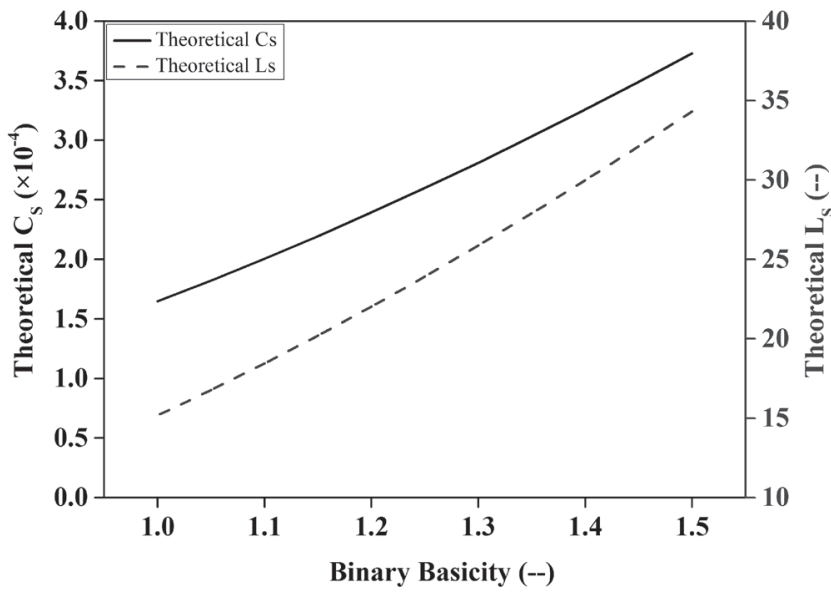

Fig. 1. Theoretical $C_{S}$ and $L_{S}$ as function of $\mathrm{R}_{2}$ in the slag at $1773 \mathrm{~K}\left(1500^{\circ} \mathrm{C}\right)$.

partial pressures, sulfur will dissolve by replacing free oxygen ions. So the trend in the figure can thus be explained by the increase of free oxygen ions when the slag becomes more basic. At the lower basicity, the $\mathrm{CaO}$ content in the slag is less, so that only a few free oxygen ions exist and this results in low $C_{S}$ and low $L_{S}$ of slags. As $\mathrm{R}_{2}$ increases, the $\mathrm{SiO}_{2}$ networks are broken into smaller anion groups and the proportion of free oxygen ions starts to increase. Therefore, the $C_{S}$ and $L_{S}$ of slags increase.

\subsubsection{Effect of $\mathrm{MgO}$}

Figure 2, in which the variations of $\mathrm{MgO}$ content are realized by adjusting $\mathrm{CaO}$ and $\mathrm{SiO}_{2}$ contents while $\mathrm{R}_{2}$ is constant, shows the effects of $\mathrm{MgO}$ content in slag on the theoretical $C_{S}$ and $L_{S}$ of slags at $1773 \mathrm{~K}\left(1500^{\circ} \mathrm{C}\right)$. It can also be seen that $\mathrm{MgO}$ increases $C_{S}$ and $L_{S}$ because it is also basic oxide like $\mathrm{CaO}$ and increases the available free oxygen ions. In addition, the effect of $\mathrm{MgO}$ on $C_{S}$ is somewhat less profound compared to $\mathrm{CaO}$ when replacing $\mathrm{SiO}_{2}$ because of calcium's much higher affinity to sulfur. ${ }^{7}$ As a result, $C_{S}$ of the slag increases from $2.49 \times 10^{-4}$ to $3.17 \times 10^{-4}$ when the $\mathrm{MgO}$ content in the slag increases from $5 \%$ to $18 \%$. However, $C_{S}$ increases from $1.65 \times 10^{-4}$ to $3.73 \times 10^{-4}$ when the $\mathrm{CaO}$ content in the slag increases from $38.03 \%$ to $45.63 \%$ in Fig. 1. And that is, effect of $\mathrm{MgO}$ on $C_{S}$ is much weaker that of $\mathrm{R}_{2}$.

\subsubsection{Effect of $\mathrm{MgO} / \mathrm{Al}_{2} \mathrm{O}_{3}$}

Figure 3 illustrates the effects of $\mathrm{MgO} / \mathrm{Al}_{2} \mathrm{O}_{3}$ in slags on $C_{S}$ and $L_{S}$ of the slags. The increase of $\mathrm{MgO} / \mathrm{Al}_{2} \mathrm{O}_{3}$ is achieved by the simultaneous increase of $\mathrm{MgO}$ and $\mathrm{Al}_{2} \mathrm{O}_{3}$ mass percent. $\mathrm{MgO}$ content increases from $2.4 \%$ to $19.95 \%$ and $\mathrm{Al}_{2} \mathrm{O}_{3}$ content increases from $6 \%$ to $19 \% . \mathrm{MgO}$ is known as basic oxide and hence increase the $C_{S}$ and $L_{S}$ of the slag, which has been displayed in Fig. 2. According to the ionic potential $\left(\mathrm{Z} / \mathrm{r}^{2}\right)$ and structural behavior of $\mathrm{Al}_{2} \mathrm{O}_{3}$, it behaves as an amphoteric oxide in the ternary $\mathrm{CaO}-\mathrm{SiO}_{2}-\mathrm{Al}_{2} \mathrm{O}_{3}$ melts, as identified by Banya. ${ }^{22)}$ However, considering the $\mathrm{CaO} / \mathrm{SiO}_{2}$ ratio in the present slags, $\mathrm{Al}^{3+}$ is typically in a tetrahedral configuration with oxygen. In this case, part of free oxygen ions will be consumed by added $\mathrm{Al}_{2} \mathrm{O}_{3}$. It can be seen in Fig. 3 that the $C_{S}$ and $L_{S}$ of slag decrease firstly and then increase with the increase of $\mathrm{MgO} / \mathrm{Al}_{2} \mathrm{O}_{3}$ in the slag.

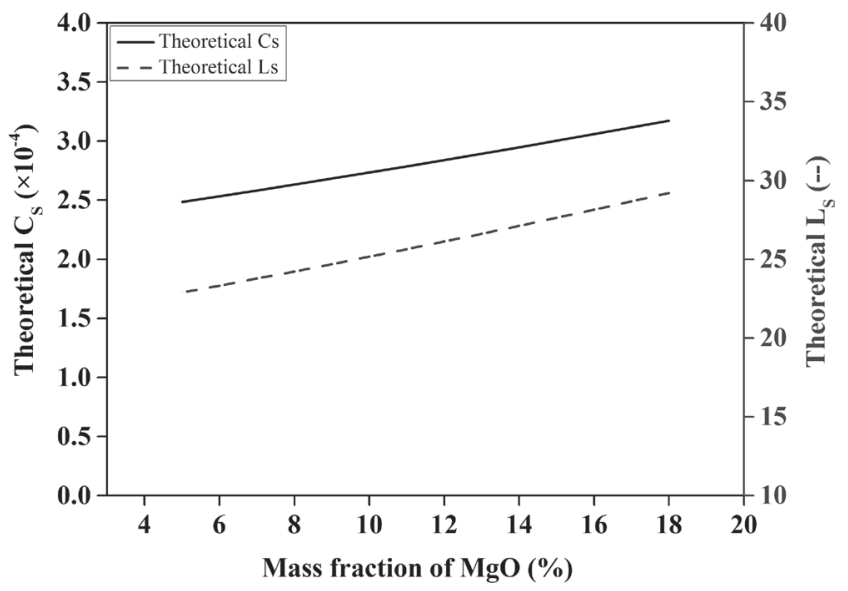

Fig. 2. Theoretical $C_{S}$ and $L_{S}$ as function of $\mathrm{MgO}$ content in the slag at $1773 \mathrm{~K}\left(1500^{\circ} \mathrm{C}\right)$

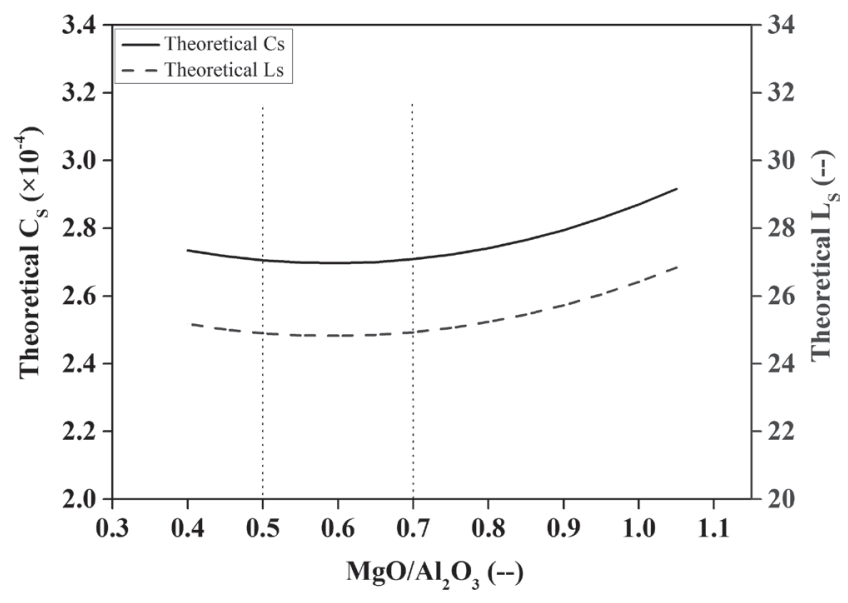

Fig. 3. Theoretical $C_{S}$ and $L_{S}$ as function of $\mathrm{MgO} / \mathrm{Al}_{2} \mathrm{O}_{3}$ ratio in the slag at $1773 \mathrm{~K}\left(1500^{\circ} \mathrm{C}\right)$.

The quaternary basicity $\left(\mathrm{R}_{4}=(\mathrm{CaO}+\mathrm{MgO}) /\left(\mathrm{SiO}_{2}+\mathrm{Al}_{2} \mathrm{O}_{3}\right)\right)$ is used to explain this phenomenon and it almost has the same variation with $C_{S}$ and $L_{S}$ of slag. $C_{S}$ and $L_{S}$ keep almost constant during interval of $\mathrm{MgO} / \mathrm{Al}_{2} \mathrm{O}_{3}$ in $0.5-0.7$. In the low $\mathrm{MgO} / \mathrm{Al}_{2} \mathrm{O}_{3}$ range, negative effect of $\mathrm{Al}_{2} \mathrm{O}_{3}$ on desulfurization, especially free oxygen ions, is stronger than positive effect of $\mathrm{MgO}$. Then positive effect of $\mathrm{MgO}$ on desulfurization becomes stronger gradually and lowers the negative effect of $\mathrm{Al}_{2} \mathrm{O}_{3}$ in the high $\mathrm{MgO} / \mathrm{Al}_{2} \mathrm{O}_{3}$ range. $\mathrm{So}, \mathrm{MgO}$ in slag helps to reduce the bad role of $\mathrm{Al}_{2} \mathrm{O}_{3}$ in desulfurization when the binary basicity of slag is constant.

\subsubsection{Effect of $\mathrm{MnO}$}

Effect of $\mathrm{MnO}$ content on $C_{S}$ and $L_{S}$ is shown in Fig. 4. It shows that $C_{S}$ and $L_{S}$ increase with the increases of $\mathrm{MnO}$ content as $\mathrm{MnO}$ is a basic oxide, which provides free oxygen ions and $\mathrm{Mn}^{2+}$ itself combines with $\mathrm{S}^{2-}$. After comparing calculated results of $\mathrm{MgO}, \mathrm{CaO}$ and $\mathrm{MnO}$ on $C_{S}$, effects of $\mathrm{CaO}$ and $\mathrm{MnO}$ are almost the same but much more profound than $\mathrm{MgO}$. The sulfide capacity increases by increasing the $\mathrm{MnO} / \mathrm{CaO}$ ratio at a fixed silica content which is greater than about $30 \mathrm{wt} \%$, whereas it decreases by increasing the $\mathrm{MnO} / \mathrm{CaO}$ ratio at silica content lower than about $30 \mathrm{wt} \%{ }^{23,24)}$ The critical $\mathrm{SiO}_{2}$ content is about $30 \mathrm{wt} \%$ based on the competitive dissolution mechanism of 


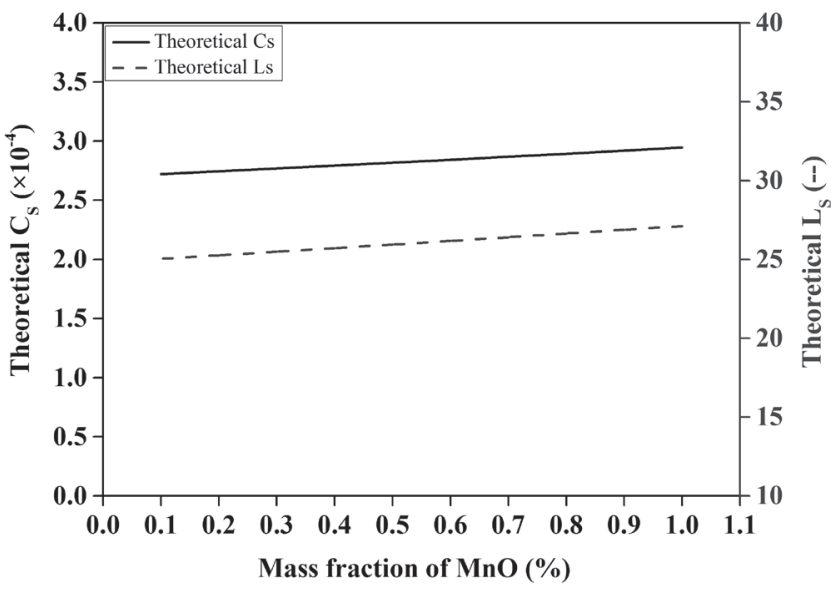

Fig. 4. Theoretical $C_{S}$ and $L_{S}$ as function of $\mathrm{MnO}$ content in the slag at $1773 \mathrm{~K}\left(1500^{\circ} \mathrm{C}\right)$.

sulfur in $\mathrm{Ca}-\mathrm{Mn}-$-silicate melts. The used $\mathrm{SiO}_{2}$ content in the calculation is $33 \mathrm{wt} \%$ and so the effects of $\mathrm{MnO}$ and $\mathrm{CaO}$ are similar in the present slag system.

\subsection{Theoretical Calculations of Viscosity and Diffusion Coefficient (Dynamics)}

Viscosity of slags is the most important parameter in the desulfurization dynamics, which determines the extent of desulfurization reactions. Variation of chemical compositions of slag has a great effect on the viscosity besides the sulfide capacity discussed previously. Slag-forming cations, such as $\mathrm{Si}, \mathrm{Ca}, \mathrm{Mg}$, and $\mathrm{Al}$, are all linked with oxygen by different bondings. There are three kinds of oxygen existing in the molten slag: the bridging oxygen $\left(\mathrm{O}^{0}\right)$ connecting elements with two oxygen bonds, non-bridging oxygen $\left(\mathrm{O}^{-}\right)$connecting elements with one oxygen bond, and free oxygen $\left(\mathrm{O}^{2-}\right)$ without oxygen bond. Usually, $\mathrm{Si}-\mathrm{O}$ tetrahedral is combined by the bridging oxygen. When the basic oxides such as $\mathrm{CaO}$ or $\mathrm{MgO}$ are added into the silicate melt, reticular complex compounds will be fractured by the non-bridging oxygen ion and the free oxygen, and viscosity will be decreased. ${ }^{25,26)}$ Effects of variation of chemical compositions on viscosity of slag at $1773 \mathrm{~K}\left(1500^{\circ} \mathrm{C}\right)$ are given below. Results are calculated by Factsage 6.4 based on Eq. (8). Diffusion coefficients are calculated according to Eq. (6).

\subsubsection{Effect of Binary Basicity $\left(\mathrm{R}_{2}\right)$}

Relationship between binary basicity $\mathrm{CaO} / \mathrm{SiO}_{2}$ and the viscosity and diffusion coefficient in slag is shown in Fig. 5. It can be seen that the viscosity of slag decreases with the increase of $\mathrm{R}_{2}$ but weakens gradually. As we all know, $\mathrm{CaO} / \mathrm{SiO}_{2}$ has a significant effect on the viscosity of slag, because the availability of free oxygen ions increases due to the $\mathrm{CaO}$ dissociation for a higher basicity. In the molten slag, the free oxygen ions can react with the bridged oxygen in the viscous units network structures to form the non-bridging oxygen. The polymerization degree of complex viscous units in the slag can be reduced and the complex viscous units are broken down into the smaller units. Therefore, the viscosity decreases, and the fluidity of slags is improved. ${ }^{27)}$ However, more addition of $\mathrm{CaO}$ exerts a limited effect when depolymerisation of the slag complex

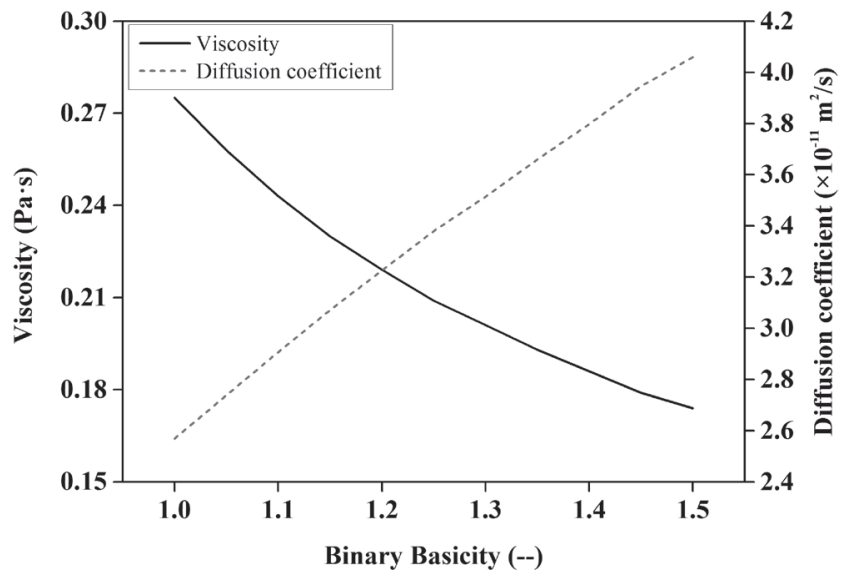

Fig. 5. Calculated viscosities and diffusion coefficient in slag based on different $\mathrm{R}_{2}$ at $1773 \mathrm{~K}\left(1500^{\circ} \mathrm{C}\right)$.

network structures has already occurred markedly because the viscosity is fairly low. ${ }^{25,28)}$ Diffusion coefficients, which represents the dynamics of desulfurization reaction, have opposite changes with viscosity, and so it will not be repeated here and after.

\subsubsection{Effect of $\mathrm{MgO}$}

Variations of viscosity and diffusion coefficient with $\mathrm{MgO}$ content in the slag are shown in Fig. 6, $\mathrm{Al}_{2} \mathrm{O}_{3}, \mathrm{MnO}$, $\mathrm{FeO}$ contents and $\mathrm{CaO} / \mathrm{SiO}_{2}$ are constant. It can be seen that the viscosity decreases with increases of $\mathrm{MgO}$ content when the $\mathrm{MgO}$ content less than $14 \mathrm{wt} \%$. This is because that $\mathrm{MgO}$ is also a basic oxide and can provides free oxygen ions to break the complex network structure into simple polymer units, such as monomers and dimmers. Furthermore, the polarizing power of $\mathrm{Mg}^{2+}$ is stronger than that of $\mathrm{Ca}^{2+}$ and $\mathrm{Mg}^{2+}$ exhibits a stronger electrostatic interaction with oxygen ions. ${ }^{29)}$ Therefore, the ability of $\mathrm{MgO}$ to offer free oxygen (FO) ions is considered to be relatively weaker than that of $\mathrm{CaO}$ and so the network breaking ability of $\mathrm{MgO}$ is not as high as that of $\mathrm{CaO} .{ }^{30)}$ Consequently, the ability of decreasing degree of polymerization and viscosity of $\mathrm{MgO}$ is weaker than that of $\mathrm{CaO}$.

Besides, results show that the viscosity of slag increases with increase of $\mathrm{MgO}$ when the $\mathrm{MgO}$ content greater than $14 \mathrm{wt} \%$ (Inflection point in the present slag system). This may be caused by the sharply increased liquidus temperature, which is also shown in Fig. 6, and so viscosity of present slag at $1773 \mathrm{~K}$ is increased by the increasing solid phase fraction after the inflection point. ${ }^{31)}$

\subsubsection{Effect of $\mathrm{MgO} / \mathrm{Al}_{2} \mathrm{O}_{3}$}

Calculation results about the effect of $\mathrm{MgO} / \mathrm{Al}_{2} \mathrm{O}_{3}$ on the viscosity and diffusion coefficient in slag are shown in Fig. 7. $\mathrm{MgO}$ content, $\mathrm{Al}_{2} \mathrm{O}_{3}$ content and $\mathrm{MgO} / \mathrm{Al}_{2} \mathrm{O}_{3}$ are all increase, other compositions are constant. Results show that viscosity of slag decreases with the increase of $\mathrm{MgO} / \mathrm{Al}_{2} \mathrm{O}_{3}$ in slag and then effect diminishes gradually and followed by increases with the increasing $\mathrm{MgO} / \mathrm{Al}_{2} \mathrm{O}_{3}$. This can be explained by two aspects, i.e., effect of $\mathrm{MgO}$ and effect of $\mathrm{Al}_{2} \mathrm{O}_{3}$. The effect of $\mathrm{MgO}$ content in slag on viscosity has been discussed in detail in the former section.

Effect of $\mathrm{Al}_{2} \mathrm{O}_{3}$ content on the viscosity of slag is attrib- 


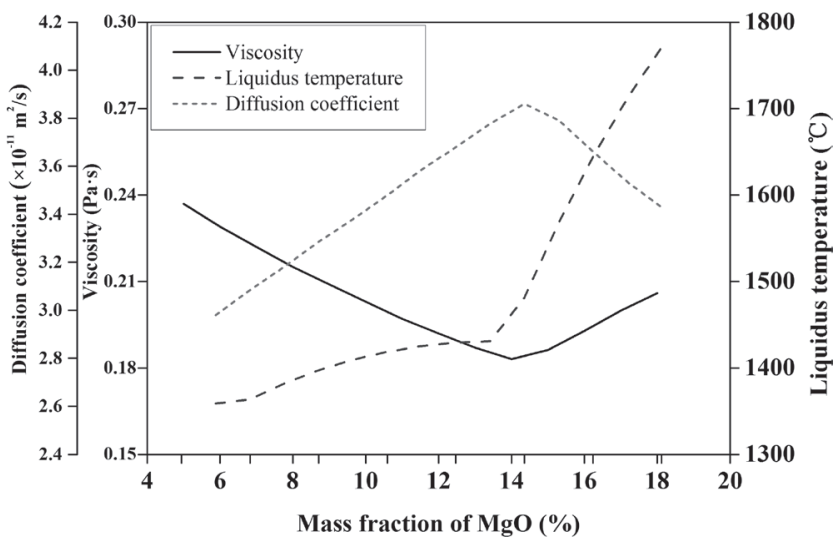

Fig. 6. Calculated viscosities, liquidus temperature of slag and diffusion coefficient based on different $\mathrm{MgO}$ contents at $1773 \mathrm{~K}\left(1500^{\circ} \mathrm{C}\right)$

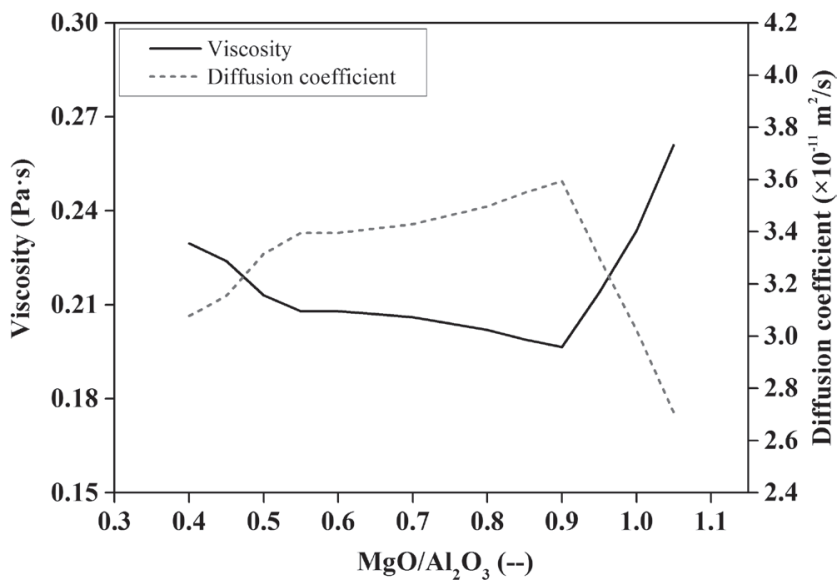

Fig. 7. Calculated viscosities and diffusion coefficient in slag based on varying $\mathrm{MgO} / \mathrm{Al}_{2} \mathrm{O}_{3}$ ratio at $1773 \mathrm{~K}\left(1500^{\circ} \mathrm{C}\right)$.

uted to the amphoteric behavior of $\mathrm{Al}_{2} \mathrm{O}_{3}$ in the aluminosilicate melts. ${ }^{32)}$ It is either a basic oxide for a network modifier or an acidic oxide for a network former depending on the slag compositions. When $\mathrm{Al}_{2} \mathrm{O}_{3}$ behaves as a network former, it can absorb the free oxygen ions to form the complex viscous units $\left[\mathrm{AlO}_{4}\right]^{5-}$ network, and $\mathrm{Al}^{3+}$ substitutes for $\mathrm{Si}^{4+}$ in $\left[\mathrm{Si}_{\mathrm{x}} \mathrm{O}_{\mathrm{y}}\right]^{\mathrm{z}-}$ complex viscous units to form the $\mathrm{Si}-\mathrm{Al}-\mathrm{O}$ composite anionic group network. ${ }^{33)}$ As a result, the polymerization degree of viscous units in the slags increases, and the slag structure becomes more complicated, leading to the increase in viscosity. However, the $\mathrm{Al}^{3+}$ ions would form the $\left[\mathrm{AlO}_{6}\right]$-octahedra for the network modifying role. ${ }^{27,34)}$

Both effects of $\mathrm{MgO}$ and $\mathrm{Al}_{2} \mathrm{O}_{3}$ on viscosity result in the relationship between $\mathrm{MgO} / \mathrm{Al}_{2} \mathrm{O}_{3}$ in slag and viscosity of slag. It can be concluded that the $\mathrm{MgO} / \mathrm{Al}_{2} \mathrm{O}_{3}$ of the slag can not to be too high or too low, and the proper range of the $\mathrm{MgO} / \mathrm{Al}_{2} \mathrm{O}_{3}$ can obviously decrease the viscosity and improve the fluidity of the slag.

\subsubsection{Effect of $\mathrm{MnO}$}

Effects of $\mathrm{MnO}$ content on the viscosity and diffusion coefficient in slag are shown in Fig. 8, in which, $\mathrm{CaO} / \mathrm{SiO}_{2}$, $\mathrm{MgO}, \mathrm{Al}_{2} \mathrm{O}_{3}$ and $\mathrm{FeO}$ contents are constant. Results show that the viscosity of slag decreases with the increase of $\mathrm{MnO}$ content. The viscosity just decreases from $0.204 \mathrm{~Pa} \cdot \mathrm{s}$

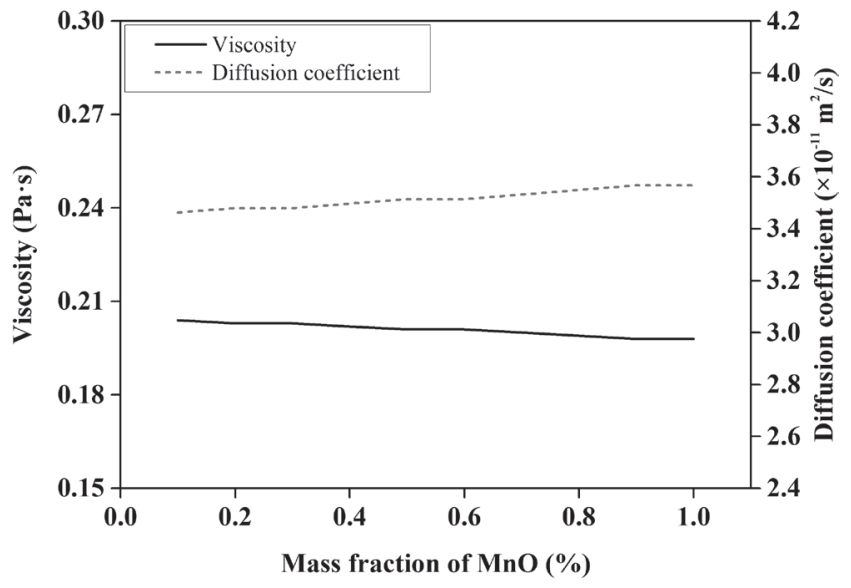

Fig. 8. Calculated viscosities and diffusion coefficient in slag based on varying $\mathrm{MnO}$ contents at $1773 \mathrm{~K}\left(1500^{\circ} \mathrm{C}\right)$.

to $0.198 \mathrm{~Pa} \cdot \mathrm{s}$ because of the small change of $\mathrm{MnO}$ content. As the role of $\mathrm{CaO}$ and $\mathrm{MgO}, \mathrm{MnO}$ is also a basic oxide and provides free oxygen to break the complex structure of slag. And so increase of $\mathrm{MnO}$ content helps to decrease the viscosity and improve the fluidity of slag.

\section{Experimental Results and Discussions}

All the theoretical calculations are only shown to indicate the qualitative effects of these compositions. And effects on thermodynamics and dynamics are discussed respectively. Therefore, desulfurization experiments are obviously needed to confirm the suitable chemical compositions of slag considering both thermodynamics and dynamics of desulfurization reaction.

Desulfurization efficiency $\left(\eta_{s}\right)$, which is calculated as Eq. (9), is defined to evaluate the desulfurization experimental results of interaction between slag and iron.

$$
\eta_{S}=\frac{[\operatorname{pct} S]_{0}-[\operatorname{pct} S]_{1}}{[\operatorname{pct} S]_{0}}
$$

where $[\text { pct } S]_{0}$ and $[p c t S]_{1}$ are the initial and the final sulfur contents in iron sample, respectively. Time for all the desulfurization experiments in this paper is 60 minutes and the reason has been explained in the former paper. ${ }^{11)}$

Detailed experimental methods have been illustrated in authors' former paper. ${ }^{11)}$ Experimental parameters and base slag compositions are decided based on actual production of COREX-3000 in Bayi Steel of China. All experiments are carried out according to the chemical compositions of slag in Table 3. Experimental results are discussed as follows.

\subsection{Experimental Effect of $\mathrm{CaO} / \mathrm{SiO}_{2}$ on Desulfurization Efficiency}

Figure 9 shows that desulfurization efficiency $\left(\eta_{s}\right)$ and sulfur distribution ratio $\left(L_{S}\right)$ increase with the increase of $\mathrm{CaO} / \mathrm{SiO}_{2}$ at $1773 \mathrm{~K}\left(1500^{\circ} \mathrm{C}\right)$. This is the combined effects of $\mathrm{CaO} / \mathrm{SiO}_{2}$ on sulfide capacity and fluidity of slag, which has been discussed detailedly in Part 3. It can be seen that the $\eta_{S}$ and $L_{S}$ increase slowly when the $\mathrm{CaO} / \mathrm{SiO}_{2}$ exceeds 1.3, which may results from the subdued improvement of $\mathrm{CaO} / \mathrm{SiO}_{2}$ on the fluidity of slag. According to Fig. 
Table 3. Chemical compositions of all slags (mass percent).

\begin{tabular}{|c|c|c|c|c|c|c|c|c|}
\hline Compositions & $\mathrm{CaO}$ & $\mathrm{MgO}$ & $\mathrm{SiO}_{2}$ & $\mathrm{Al}_{2} \mathrm{O}_{3}$ & $\mathrm{FeO}$ & $\mathrm{MnO}$ & $\mathrm{R}_{2}$ & $\mathrm{MgO} / \mathrm{Al}_{2} \mathrm{O}_{3}$ \\
\hline \multirow[t]{6}{*}{ Base Slag } & 42.72 & 9.83 & 33.33 & 13.02 & 0.98 & 0.12 & 1.28 & 0.75 \\
\hline & 38.95 & 9.83 & 37.10 & 13.02 & 0.98 & 0.12 & 1.05 & 0.75 \\
\hline & 40.68 & 9.83 & 35.37 & 13.02 & 0.98 & 0.12 & 1.15 & 0.75 \\
\hline & 43.69 & 9.83 & 32.36 & 13.02 & 0.98 & 0.12 & 1.35 & 0.75 \\
\hline & 45.01 & 9.83 & 31.04 & 13.02 & 0.98 & 0.12 & 1.45 & 0.75 \\
\hline & 44.84 & 6.00 & 35.04 & 13.02 & 0.98 & 0.12 & 1.28 & 0.46 \\
\hline \multirow{3}{*}{$\mathrm{MgO}$} & 43.72 & 8.00 & 34.16 & 13.02 & 0.98 & 0.12 & 1.28 & 0.61 \\
\hline & 41.48 & 12.00 & 32.40 & 13.02 & 0.98 & 0.12 & 1.28 & 0.92 \\
\hline & 40.35 & 14.00 & 31.53 & 13.02 & 0.98 & 0.12 & 1.28 & 1.08 \\
\hline \multirow{4}{*}{$\mathrm{MgO} / \mathrm{Al}_{2} \mathrm{O}_{3}$} & 47.69 & 4.95 & 37.26 & 9.00 & 0.98 & 0.12 & 1.28 & 0.55 \\
\hline & 45.33 & 7.15 & 35.42 & 11.00 & 0.98 & 0.12 & 1.28 & 0.65 \\
\hline & 39.94 & 12.75 & 31.21 & 15.00 & 0.98 & 0.12 & 1.28 & 0.85 \\
\hline & 36.91 & 16.15 & 28.84 & 17.00 & 0.98 & 0.12 & 1.28 & 0.95 \\
\hline \multirow{4}{*}{$\mathrm{MnO}$} & 42.59 & 9.83 & 33.28 & 13.02 & 0.98 & 0.30 & 1.28 & 0.75 \\
\hline & 42.48 & 9.83 & 33.19 & 13.02 & 0.98 & 0.50 & 1.28 & 0.75 \\
\hline & 42.37 & 9.83 & 33.10 & 13.02 & 0.98 & 0.70 & 1.28 & 0.75 \\
\hline & 42.26 & 9.83 & 33.01 & 13.02 & 0.98 & 0.90 & 1.28 & 0.75 \\
\hline
\end{tabular}

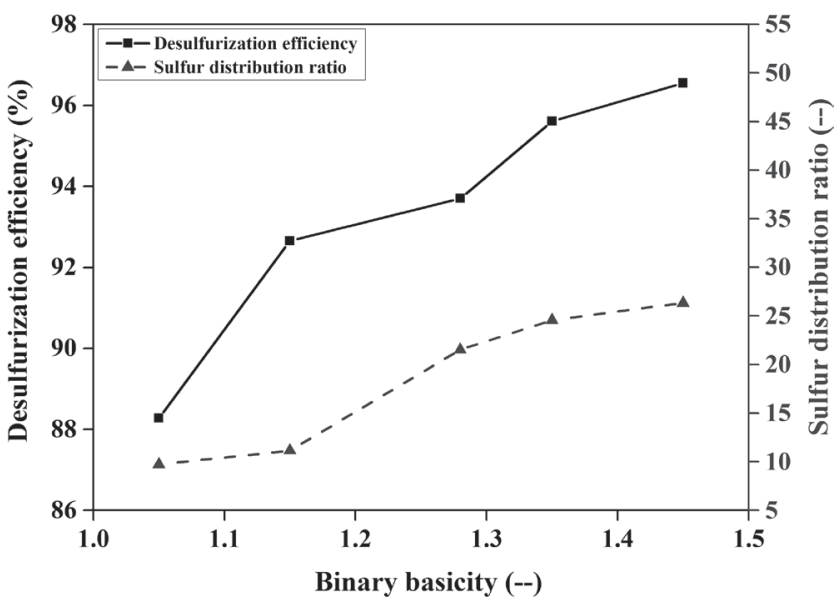

Fig. 9. Experimental results on the relationship between $\eta_{S}, L_{S}$ and $\mathrm{R}_{2}$ in the slag at $1773 \mathrm{~K}\left(1500^{\circ} \mathrm{C}\right)$.

9, it is suggested that the $\mathrm{CaO} / \mathrm{SiO}_{2}$ of slag in Bayi Steel should be controlled in the range of 1.20-1.30.

\subsection{Experimental Effect of MgO content on Desulfur- ization Efficiency}

Figure 10 illustrates the variation of the $\eta_{S}$ and $L_{S}$ with the $\mathrm{MgO}$ content in the slag sample at $1773 \mathrm{~K}\left(1500^{\circ} \mathrm{C}\right)$. It can be seen that the $\eta_{S}$ and $L_{S}$ increase gently with the increase of $\mathrm{MgO}$ content of slag. On the one hand, $\mathrm{MgO}$ is a basic oxide and it has favorable effects on sulfide capacity and fluidity of slag, and so improves the desulfurization efficiency of slag. On the other hand, $\mathrm{MgO}$ has weaker effects on desulfurization, compared with that of $\mathrm{CaO}$, because of its weaker ability of offering free oxygen ions. Furthermore, effect of $\mathrm{MgO}$ should be associated with that of $\mathrm{Al}_{2} \mathrm{O}_{3}$. Based on these, the $\mathrm{MgO}$ content of slag in Bayi Steel should be controlled in the range of $10 \mathrm{wt} \%$ to $12 \mathrm{wt} \%$.

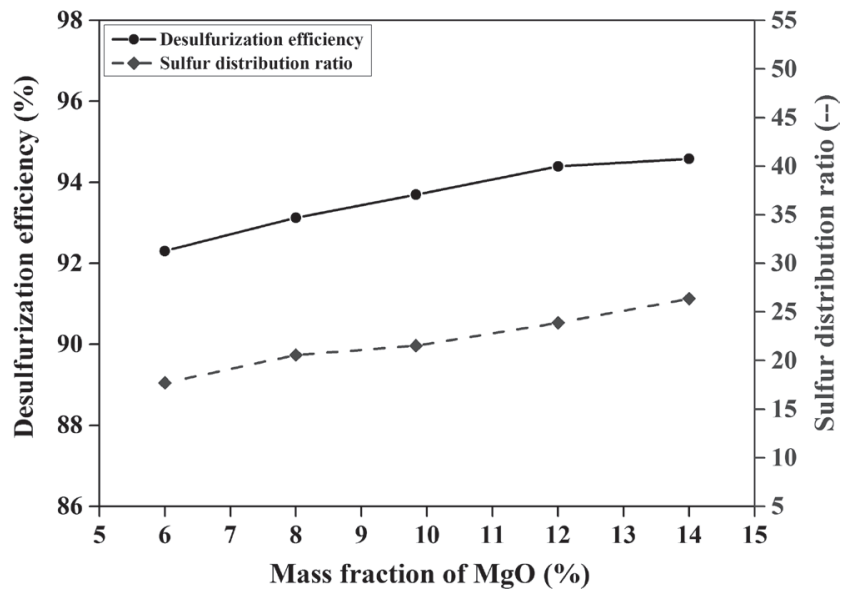

Fig. 10. Experimental results on the relationship between $\eta_{S}, L_{S}$ and $\mathrm{MgO}$ content in the slag at $1773 \mathrm{~K}\left(1500^{\circ} \mathrm{C}\right)$.

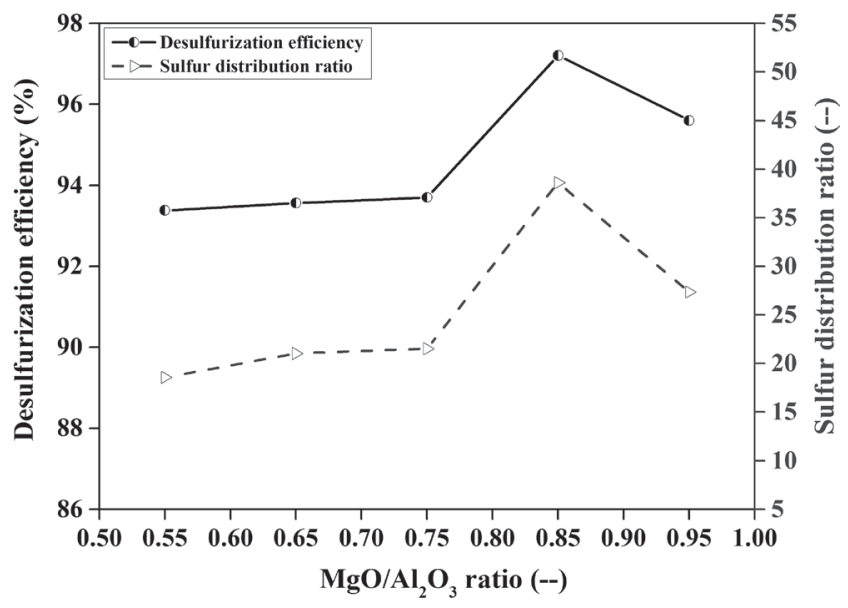

Fig. 11. Experimental results on the relationship between $\eta_{S}, L_{S}$ and $\mathrm{MgO} / \mathrm{Al}_{2} \mathrm{O}_{3}$ in the slag at $1773 \mathrm{~K}\left(1500^{\circ} \mathrm{C}\right)$.

\subsection{Experimental Effect of $\mathrm{MgO} / \mathrm{Al}_{2} \mathrm{O}_{3}$ on Desulfuriza- tion Efficiency}

Experimental results about the effect of $\mathrm{MgO} / \mathrm{Al}_{2} \mathrm{O}_{3}$ ratio on desulfurization efficiency and sulfur distribution ratio are shown in Fig. 11. Both the effects of $\mathrm{MgO} / \mathrm{Al}_{2} \mathrm{O}_{3}$ on sulfide capacity and viscosity have opposite tendency before and after the inflection points. Considering these two aspects and experimental results show that inflection point is still exists in the $\eta_{S}$ and $L_{S}-\mathrm{MgO} / \mathrm{Al}_{2} \mathrm{O}_{3}$ curves, and the inflection point appears when the $\mathrm{MgO} / \mathrm{Al}_{2} \mathrm{O}_{3}$ equals to 0.85 . In addition, the desulfurization efficiency and sulfur distribution ratio increase gently when the $\mathrm{MgO} / \mathrm{Al}_{2} \mathrm{O}_{3}$ increases from 0.55 to 0.75 , and it may be caused by the little change in sulfide capacity, which is shown in Fig. 3. $\eta_{S}$ and $L_{S}$ increase sharply when the $\mathrm{MgO} / \mathrm{Al}_{2} \mathrm{O}_{3}$ increase from 0.75 to 0.85 because of the increased sulfide capacity and decreased viscosity. And then $\eta_{S}$ and $L_{S}$ decrease when the $\mathrm{MgO} / \mathrm{Al}_{2} \mathrm{O}_{3}$ exceeds 0.85 on account of the sharply increased viscosity, which is shown in Fig. 7. Consequently, the applicable $\mathrm{MgO} / \mathrm{Al}_{2} \mathrm{O}_{3}$ for the present slag system ranges from 0.80 to 0.90 .

\subsection{Experimental Effect of $\mathrm{MnO}$ on Desulfurization Efficiency}

Figure 12 shows the experimental results about the effect 


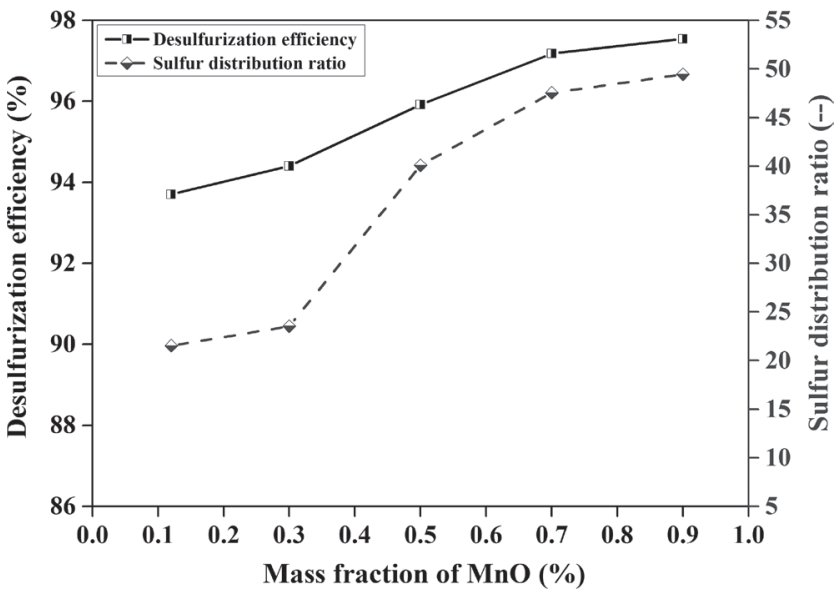

Fig. 12. Experimental results on the relationship between $\eta_{S}, L_{S}$ and $\mathrm{MnO}$ content in the slag at $1773 \mathrm{~K}\left(1500^{\circ} \mathrm{C}\right)$.

of $\mathrm{MnO}$ content on desulfurization efficiency. It can be seen that $\eta_{S}$ and $L_{S}$ increase sharply with the increase of $\mathrm{MnO}$ content in the slag. It seems that the experimental results of the effect of $\mathrm{MnO}$ content are more prominent than the theoretical calculation results. This may be explained by the coupled reactions among $(\mathrm{MnO})-\left(\mathrm{SiO}_{2}\right)-[\mathrm{Mn}]-[\mathrm{Si}]$, coupled reactions promote the desulfurization reaction between slag and hot metal. ${ }^{11)}$ Based on these, the appropriate $\mathrm{MnO}$ content of slag may be controlled in the range of $0.4 \mathrm{wt} \%$ to $0.7 \mathrm{wt} \%$.

\section{Conclusions}

Theoretical calculations of sulfide capacity and viscosity of different slag are carried out to study the effects of chemical compositions on desulfurization. And then experiments are conducted to determine the optimal chemical composition ranges of slag in the COREX-3000 process. The following conclusions are drawn:

(1) The theoretical calculation results of sulfide capacity show that the increase of $\mathrm{CaO} / \mathrm{SiO}_{2}, \mathrm{MgO}$ content and $\mathrm{MnO}$ content are all benefit for the improvement of sulfide capacity of slag. And for the relationship between $\mathrm{MgO} / \mathrm{Al}_{2} \mathrm{O}_{3}$ and $C_{S}$, inflection point is exist and effects are opposite before and after the inflection point.

(2) The theoretical calculation results of viscosity show that the viscosity decreases with the increase of $\mathrm{CaO} / \mathrm{SiO}_{2}$ and $\mathrm{MnO}$ content in the slag. But for $\mathrm{MgO}$ content and $\mathrm{MgO} / \mathrm{Al}_{2} \mathrm{O}_{3}$ in the slag, inflection points are both exist and viscosity decreases with the increase of $\mathrm{MgO}$ content and $\mathrm{MgO} / \mathrm{Al}_{2} \mathrm{O}_{3}$ before the inflection points and then increase.

(3) Experimental results, which combine both sulfide capacity and viscosity of slag, verify the effects of slag compositions in theoretical calculations and suggested ranges for each parameter are given for the production in the COREX-3000 process.

\section{Acknowledgments}

The authors are grateful for support from Fundamental Research Funds for the Central Universities (Grant No. FRF-IC-18-010) and China Postdoctoral Science Foundation (Grant No. 2017M610769) for their financial supports.

\section{REFERENCES}

1) S. Pal and A. K. Lahiri: Metall. Mater. Trans. B, 34B (2003), 103

2) Y. X. Qu, Z. S. Zhou and Y. P. Xiao: ISIJ Int., 52 (2012), 2186.

3) K. P. Du, S. L. Wu, Z. K. Zhang, F. Chang and X. L. Liu: ISIJ Int., 54 (2014), 2737.

4) S. L. Wu, L. X. Wang, M. Y. Kou, Y. J. Wang and J. C. Zhang: Metall. Mater. Trans. B, 48B (2017), 276.

5) E. Scheepers, J. J. Eksteen and C. Aldrich: Miner. Eng., 19 (2006), 1163.

6) P. K. Iwamasa and R. J. Fruehan: Metall. Mater. Trans. B, 28B (1997), 47

7) A. Carl and S. C. Du: Metall. Mater. Trans. B, 46B (2015), 2609.

8) S. Amitabh, G. Märten, A. K. Lahiri and S. Seetharaman: Metall. Mater. Trans. B, 37B (2006), 941

9) V. Seshadri, C. A. Silva, I. A. Silva and P. Krüger: ISIJ Int., 37 (1997), 21.

10) Y. Nakai, N. Kikuchi, Y. Miki, Y. Kishimoto, T. Isawa and T. Kawashima: ISIJ Int., 53 (2013), 1020.

11) L. X. Wang, S. L. Wu, M. Y. Kou, B. B. Du, Y. N. Lu and K. Gu: Metall. Mater. Trans. B, 49B (2018), 89.

12) M. A. T. Andersson, P. G. Jonsson and M. Hallberg: Ironmaking Steelmaking, 27 (2009), 286.

13) C. J. B. Fincham and F. D. Richardson: Proc. R. Soc., 223 (1954), 40 .

14) G. H. Zhang, K. C. Chou and U. Pal: ISIJ Int., 53 (2013), 761.

15) Y. B. Kang and J. H. Park: Metall. Mater. Trans. B, 42B (2011), 1211.

16) H. J. Guo: Metallurgical Physical Chemistry, 2nd ed., China Metallurgical Industry Press, Beijing, (2012), 41, 47.

17) Y. J. Liang and Y. C. Che: CODATA Key Values for Thermodynamics, 1st ed., Northeastern University Press, Shenyang, (1993), 508.

18) A. Einstein: Ann. Phys., 19 (1906), 289.

19) H. C. Brinkman: J. Chem. Phys., 20 (1952), 571

20) G. M. Moldoveanu, A. A. Minea, M. Lacob, C. Ibanescu and M. Danu: Thermochim. Acta, 659 (2018), 203.

21) T. X. Zhu, K. S. Coley and G. A. Irons: Metall. Mater. Trans. B, 43B (2012), 751.

22) S. Ban-ya and M. Hino: Tetsu-to-Hagané, 74 (1988), 1701

23) J. H. Park: Steel Res. Int., 84 (2013), 664.

24) G. H. Park, Y. B. Kang and J. H. Park: ISIJ Int., 51 (2011), 1375.

25) L. Yao, S. Ren, X. Q. Wang, Q. C. Liu, L. Y. Dong, J. F. Yang and J. B. Liu: Steel Res. Int., 87 (2016), 241.

26) L. Yao, S. Ren, G. Q. Liu, Q. C. Liu, M. Kong and J. Yang: Metall. Res. Technol., 112 (2015), 1.

27) C. Feng, M. S. Chu, J. Tang, Y. T. Tang and Z. G. Liu: Steel Res. Int., 87 (2016), 1274.

28) Z. Yan, X. Lv, J. Zhang, Y. Qin and C. Bai: Can. Metall. Q., 55 (2016), 186

29) X. H. Huang: Metallurgical Principles in Ironmaking and Steelmaking, 4th ed., China Metallurgical Industry Press, Beijing, (2013), 167.

30) Y. M. Gao, S. B. Wang, C. Hong, X. J. Ma and F. Yang: Int. J. Miner. Metall. Mater., 21 (2014), 353.

31) J. R. Kim, Y. S. Lee, D. J. Min, S. M. Jung and S. H. Yi: ISIJ Int., 44 (2004), 1291.

32) J. H. Park, D. J. Min and H. S. Song: Metall. Mater. Trans. B, 35B (2004), 269

33) X. L. Tang, Z. T. Zhang, M. Guo, M. Zhang and X. D. Wang: J. Iron Steel Res. Int., 18 (2011), 1.

34) X. F. Zhang, T. Jiang, X. X. Xue and B. S. Hu: Steel Res. Int., 87 (2016), 87. 